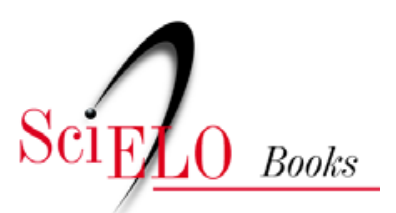

\title{
O anacronismo penitenciário
}

\author{
Maria Fernanda Tourinho Peres
}

\section{SciELO Books / SciELO Livros / SciELO Libros}

PERES, M.F.T. O anacronismo penitenciário. In: COELHO, M.T.Á.D., and CARVALHO FILHO, M.J., orgs. Prisões numa abordagem interdisciplinar [online]. Salvador: EDUFBA, 2012, pp. 7-9. ISBN 978-85-232-1735-8. Availablefrom: doi: 10.7476/9788523217358.001. Also available in ePUB from: http://books.scielo.org/id/7mkg8/epub/coelho-9788523217358.epub.

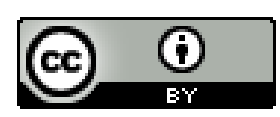

All the contents of this work, except where otherwise noted, is licensed under a Creative Commons Attribution $\underline{4.0 \text { International license. }}$

Todo o conteúdo deste trabalho, exceto quando houver ressalva, é publicado sob a licença Creative Commons Atribição 4.0.

Todo el contenido de esta obra, excepto donde se indique lo contrario, está bajo licencia de la licencia Creative Commons Reconocimento 4.0. 


\section{O anacronismo penitenciário}

Nas últimas décadas do século XX consolida-se em grande parte dos países ocidentais uma política de encarceramento em massa. (SALLA, 2001) No Brasil, exemplos máximos dessa tendência encontram-se nos Estados de São Paulo e Minas Gerais. Em São Paulo, por exemplo, a taxa de aprisionamento passou de 276,5 por $100 \mathrm{mil}$ habitantes com mais de 18 anos, em 1996, para 524,6 em 2008, um crescimento de cerca de 90\%. (PERES et al., 2011) No Brasil, a população prisional passou de 361.402 presos em 2005 para 473.636 em 2009, segundo dados oficiais do Sistema Integrado de Informações Penitenciárias do Ministério da Justiça (INFOPEN/MJ). (BRASIL, 2012) O crescimento da população carcerária é destacado no $4^{\circ}$ Relatório Nacional sobre Direitos Humanos no Brasil, publicado em 2010 pelo Núcleo de Estudos da Violência da Universidade de São Paulo. Esse crescimento ocorreu em todas as regiões do país e na quase totalidade dos estados, sendo mais acentuado na Bahia (94,8\%) e em São Paulo (63,6\%). (NEV/USP, 2010) Cabe ressaltar que o aumento no número de presos não foi acompanhado por um aumento da mesma ordem no número de vagas no sistema, embora tenham sido criadas novas vagas e novos estabelecimentos penitenciários. Entre 2005 e 2009 o número de vagas passou de 206.559 para 294.684, e o número de estabelecimentos penitenciários cresceu de 1.020 em 2006 para 1.134 em 2008, ainda segundo os dados oficiais do INFOPEN/MJ. Permanece, entretanto, o grave e crônico problema da superlotação: a relação entre o número de presos e o número de vagas no sistema penitenciário se mantém na ordem de 1,4 presos para cada vaga disponível, considerando o período entre 2005 e 2009. (BRASIL, 2012)

Os dados acima põem em evidência a atualidade da temática desta coletânea. O livro Prisões numa abordagem interdisciplinar nos brinda com distintos olhares sobre um dos nós mais difíceis de serem 
desatados no percurso que temos trilhado para a constituição de uma sociedade democrática e de respeito aos Direitos Humanos: a questão penitenciária. Nesse sentido, é importante ressaltar que a política de encarceramento em massa, o crescimento da população carcerária e a construção de novas instituições prisionais - algumas de segurança máxima, seguindo a tendência da política de encarceramento norte-americana - não decorrem da constatação de que a política prisional e a instituição prisão vêm tendo, ao longo dos anos, bons e promissores resultados no que se refere à sua "vocação" para a "recuperação" de criminosos. São múltiplos e patentes os sinais de que o sistema é falho e que o modelo do aprisionamento como forma privilegiada de punição está longe de ser o ideal. O aumento da criminalidade, seja em termos quantitativos, seja pelo surgimento de novas modalidades criminais (SALLA, 2001), atesta que o esperado efeito dissuasório não ocorre como esperado. As múltiplas e gritantes "crises" do sistema penitenciário, com rebeliões, fugas, denúncia de tortura de presos e múltiplas formas de violação de direitos somam-se à infiltração do crime organizado em seu interior e à corrupção dos agentes que, a princípio, seriam responsáveis pela manutenção da lei e da ordem.

Dessa forma, mostra-se em certo sentido anacrônico esse avanço do sistema punitivo prisional: investe-se num modelo falido ao mesmo tempo em que se aposta, no nível discursivo, em modelos alternativos - estes ainda longe do centro da política penal nacional. Esse anacronismo, entretanto, não deve nos causar surpresas. A prisão é uma instituição que nasce pautada nessa condição. Basta lembrar que, junto com o surgimento da prisão como instituição central para a política punitiva, brilhantemente trabalhado por Foucault (1987), surgem as propostas de sua reforma. A prisão já nasce fadada a falir, mas, apesar disto, mantém-se e expande-se no mundo contemporâneo. Para Salla (2001), um dos maiores especialistas em estudos sobre o sistema penitenciário no Brasil, esta sobrevida da prisão, apesar da falência do modelo prisional em sua proposta de "recuperação" do criminoso, só pode ser compreendida se levarmos em conta a sua função nas sociedades modernas, seguindo as pistas deixadas por Foucault em Vigiar e Punir.

Tomar a prisão e a população prisional como objeto de estudo e reflexão é ainda um desafio. São escassos os dados disponíveis e difíceis 
os caminhos da pesquisa no sistema penitenciário. Dessa forma, os trabalhos apresentados neste livro vêm preencher uma lacuna importante, especialmente por sua abordagem interdisciplinar. Os estudos e pesquisas que se originam em diversos campos do conhecimento, apresentados nesta coletânea, compõem um quadro rico que explora dimensões distintas de um grave e crônico problema nacional. Esperamos que seja um estímulo ao desenvolvimento de novas pesquisas e à publicação de cada vez mais estudos sobre a questão penitenciária. Parabéns aos organizadores e aos autores!

São Paulo, 27 de janeiro de 2012.

Maria Fernanda Tourinho Peres Departamento de Medicina Preventiva Faculdade de Medicina-USP

Núcleo de Estudos da Violência-USP

\section{Referências}

BRASIL. Ministério da Justiça. Sistema Integrado de Informações

penitenciárias do Ministério da Justiça (INFOPEN/MJ).

Dados disponíveis em: <http://portal.mj.gov.br/data/Pages/

MJD574E9CEITEMIDC37B2AE94C6840068B1624D28407509CPTBRNN.

htm>. Acesso em: 27 jan. $2012>$.

FOUCAULT, M. Vigiar e Punir. Nascimento da prisão. 9. Ed. Tradução

Ligia M. Pondé Vassallo. Petrópolis: Vozes, 1987.

NEV/USP - NÚCLEO DE ESTUDOS DA VIOLÊNCIA DA UNIVERSIDADE

DE SÃO PAULO. $4^{\circ}$ Relatório Nacional sobre os Direitos Humanos no

Brasil- NEV/USP, 2010. Disponível em: < http://www.nevusp.org > Acesso em: 26 jan. 2012.

PERES, Maria Fernanda Tourinho et al. Queda dos homicídios no Município de São Paulo: uma análise exploratória de possíveis condicionantes. Revista Brasileira de Epidemiologia, v. 14, n. 4, p. 709-21, 2011.

SALLA, F. A retomada do encarceramento, as masmorras High Tech e a atualidade do pensamento de Michel Foucault. Cadernos

da F.F.C, Marília: UNESP, v. 9, n. 1, p. 35-58, 2001. Disponível em:< http://www.nevusp.org/portugues/index.php?option =com_ content\&task $=$ view\&id $=1016 \&$ Itemid $=118>$. Acesso em: 26 jan. 2012. 